\title{
Prayer and Praise in the City of Assur
}

Who, what, and where, by what helpe, and by whose: Why, how, and when, doe many things disclose.

Thomas Wilson, Arte of Rhetorique Book 1; ed. Mair (1909: 17)

Nicholas' many fields of academic enquiry include Assyrian urban life and bureaucracy, as well as Turkish archaeology. I hope all these aspects are reflected by this study of a composition relating to the cult of the city of Assur known from two tablets excavated at Huzirina.

\begin{abstract}
This article reassesses a Neo-Assyrian composition of prayer and praise focused on the city of Assur. An assessment of the manuscripts is followed by a score edition of the better preserved passages that includes new readings and highlights the poetic structure. A study of the content considers setting, protagonists and voice, as well as the key themes in relation to divinehuman communication and poetic structure. Wider literary contexts help situate the composition within ancient Mesopotamian scholarship. The study concludes by suggesting that Akkadian compositions of prayer and praise focusing on a particular city may have been an ideologically driven Assyrian innovation under Esarhaddon.
\end{abstract}

\section{Manuscript Sources}

A composition of prayer and praise stemming from the cult of the city of Assur, deified as the god Aššur, is partially preserved on two tablets from Huzirina, corresponding to modern Sultantepe in Turkey. ${ }^{1)}$ The Assur composition is incompletely preserved on two damaged tablets that are partial duplicates, both in the collections of the Archaeological Museum in Ankara. The tablet pieces were excavated in 1951 and 1952 at Huzirina and were published in hand copy, S.U. 51/124 + 52/154 as STT 87, here designated MS A, and S.U. 51/26 + 51/54A + 51/188 as STT 371, here designated MS B (Gurney and Finkelstein 1957: iv-v, 7, 13, CIX; Gurney and Hulin 1964: iii-iv, 19, 24, 31, CCLIV).2) The original excavation photographs, formerly held by O. R. Gurney, are unpublished. The Cuneiform Digital Library Initiative catalogues STT 87 as P338404 and STT 371 as P338686 with summary information and reproductions of the hand copies but no photographs (<http://cdli.ucla.edu/P338404>;

<http://cdli.ucla.edu/P338686>. Accessed 11/06/2014). ${ }^{3)}$ Deller (1965: 467-64, 476)

did ground-breaking work on both manuscripts and recorded additional

collations made by Gurney in the Archaeological Museum in July 1965.

Livingstone (1989: no. 10; XXV-VI, 24-26, 178, microfiche) published a composite edition with two collations from excavation photographs and a microfiche score of the duplicate lines. The composition is listed by Foster (2007: 2.13.9 'In Praise of Assur') but, without reference to Livingstone's edition, it is described as 'too broken for comprehension'. As part of The Corpus of Ancient Mesopotamian Scholarship (CAMS) Van Buylaere (2011a; 2011c) published individual online editions of both manuscripts and also had access to the excavation photographs.

The tablets are part of a well-known scholarly library that included a number of hymns and prayers. Capraro (2001) and Robson (2013: 48-50) give overviews of the library, and the CAMS textual database, with introductory material by Clancier (2012), is a useful 
resource. The datable tablets span the period 718-616 BCE (Lambert 1959: 122; Capraro 2001: 207) and Huzirina was probably destroyed in 610/609 BCE, when nearby Harrān fell to the Babylonians and their allies (Glassner 2004: 222-25; Postgate 1975: 124; Radner 2012: 287). The references to Qurdi-Nergal in five colophons, two of them datable to 701 BCE, probably concern the same man and he has become particularly associated with the library (Baker 2002: 1024-25). The orthography of tablets from this library in Huzirina can have a distinctive character and scribal errors are not uncommon (Lambert 1959: 124-26; Capraro 2001: 208-209; see also George 2003: 369-71).

STT 87 (MS A) is a tablet of portrait format with a preserved length of $130 \mathrm{~mm}$ and a full width of $68 \mathrm{~mm}$. The full length is unknown, because the bottom of the obverse and corresponding top of the reverse are lost. This slim one-column tablet contained the Assur composition, partially preserving 34 lines on the obverse and 14 lines on the reverse, and a four-line colophon. A vertical, central double ruling bisects the whole obverse and reverse, as preserved. After a double horizontal ruling, the lines of the colophon are evenly and generously spaced to occupy the remainder of the reverse. The vertical double ruling is related to the composition's poetic structure. The script is Neo-Assyrian and the dialect is literary Neo-Assyrian, which includes some Babylonian features (Deller 1965: 463).

STT 371 (MS B) is an extract tablet with a chunkier portrait format and its full size is $96 \mathrm{~mm}$ long by $75 \mathrm{~mm}$ wide. This one-column tablet contained ruled-off extracts and can be considered as a school tablet related to Type $2 \mathrm{a}$ (Gesche 2001: 50). The first extract provides a duplicate, with substantial variation, to part of the Assur composition: STT 8717 27 // STT 371 1-9. The continuous passage chosen as an excerpt begins with the prayers for particular staples, namely oil, wool, bread and beer, and ends with the beginning of the harvest prayer. The excerpt otherwise consists of statements about cultic observance in Assur, specifically fixed offerings to Aššur and Ellil, as the way to secure divine favour and happiness, followed by a prayer for divine protection. Thus, the excerpt is coherent and encapsulates the main message of the composition. After a ruling, a three-line extract from a prayer for the king (STT 371 10-12) is followed by another ruling and seven lines of commentary involving aspects of power and deities, probably including Aššur and Mullissu as the father and mother of the Assyrian king (STT 371 13-19). On the badly damaged reverse ten lines are followed by a ruling and blank space (Van Buylaere 2011c). Thus, as preserved, Assyrian royal cult can be seen as a unifying theme. The script and dialect are Neo-Assyrian (Deller 1965: 463-64).

In two instances two lines in MS A are written as one line in MS B without any marker of line division between them: A 23-24 // B 7 and A 26-27 // B 9. The elegant literary tablet MS A is narrower and, although it is the product of a junior apprentice scribe, it pays careful attention to the composition's poetic structure. In MS A the tablet line division follows the poetic line division and a double vertical ruling corresponds to the boundaries between poetic feet. MS B, however, is a relatively short extract in a school excerpt text and has inferior lineation. Both manuscripts have errors in keeping with their nature as scribal training

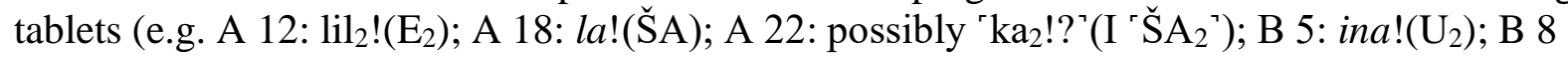
possibly $t i$ ??(UD U)). It is noticeable that there are considerable divergences in phrasing, particularly with verbal forms (e.g. A 17-20 // B 1-4; A 22 // B 6).

In terms of the work's date of composition Esarhaddon (680-669 BCE) is named in a prayer in STT 8714 (see edition below). The two manuscripts cannot be dated precisely but, as noted above, the latest datable tablet from this library is from $616 \mathrm{BCE}$ and Huzirina was probably destroyed in 610/609 BCE. The undated colophon of STT 87 (MS A) reads as follows:

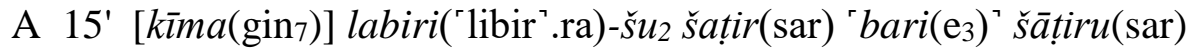 m. $\cdot{ }^{\prime} u^{\urcorner}$mutaqqin $(\mathrm{lal})^{\text {in }}$-aš-šur šam-luz-u daq-qu

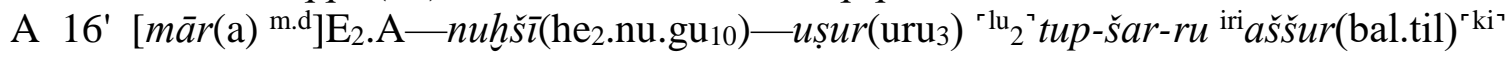




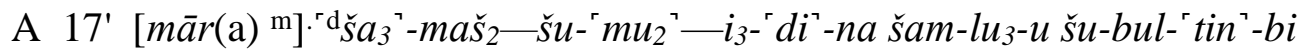

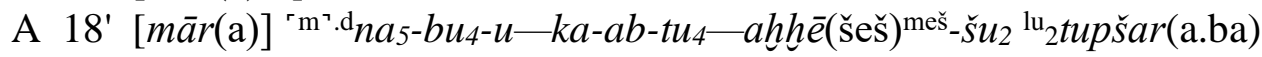

${ }^{i r i} k u t \hat{\imath}\left({ }^{\circ} \mathrm{gu}_{2}{ }^{\top} \cdot\left[\mathrm{du}_{8} \cdot \mathrm{a}\right]\right)\left[{ }^{\mathrm{ki}}\right]$

STT 87 rev. 15'-18' (A); see Hunger 1968: 371

A $15^{\prime}$ Written (and) checked [according to] its original. Writer: Mutaqqin-Aššur, junior apprentice scribe,

A 16' [son of] Ea-nuhšš-ușur, scribe of the city of Assur,

A 17' [son of] Šamaš-šumu-iddina, young apprentice scribe,

A 18' [son of] Nabû-kabtu-ahhěšu, scribe of Cutha.

As noted by Hunger (1968: 371), this colophon includes cryptographic writings. This indicates a high degree of self-conscious scholarship that is in keeping with the scribe's elaborate professional pedigree, as well as with the tablet's shape, rulings and line spacing. This colophon gives us a snapshot of members of a scribal family at different locations and various stages of professional development. The family moved progressively northwards, with an ancestor in Cutha in northern Babylonia, a father in the city of Assur and his son, the current junior apprentice scribe, in Huzirina. This trajectory suggests forced movement of professional personnel as part of Assyrian imperial policy, rather than some kind of 'minor private school' (cf. Robson 2011: 564-65; Robson 2013: 50, 55). The current junior apprentice scribe has an Assyrian name containing the theophoric element - a ̌s-šur and his father is a scribe of the city of Assur, written with the literary name ${ }^{\text {iri }} a \check{s ̌ s} u r^{\prime}$ (bal.til) ${ }^{r k i\urcorner}$ (see George 1992: 459). This suggests an Assyrian influence on the family's name-giving practices. The information given in the colopohon about the scribe and his family is in keeping with the decision to copy a scholarly composition celebrating the city of Assur and its cult.

Edition of STT 87 11-30, rev. 2'-14' (A); STT 371 1-9 (B)

The better preserved passages are presented in a score edition. This includes new readings and interpretations, and also highlights the poetic structure and manuscript variants. In each couplet the two lines are grouped together, with the second line indented in translation. When there are duplicate versions of a couplet, often with significant variation, these are arranged consecutively to aid comparison. The vertical double ruling on the tablet STT 87 is marked by $\|$ in the transliteration. As manuscript sigla, $\mathrm{A}=$ STT 87 and $\mathrm{B}=$ STT 371 .

Transliteration of STT 87 11-30 (A) // STT 371 1-9 (B)

Obverse

A 11 [x x] 'mul'-la-a $\|$ mul-la-a pan-di-šu-un

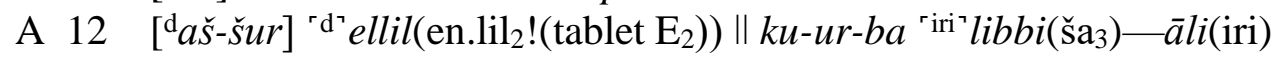

A $13[\mathrm{x} \mathrm{x}]{ }^{\ulcorner} m u l '-l i \| a-n a k i-\check{s} a_{2}-d i-\check{s} u_{2}-n u$

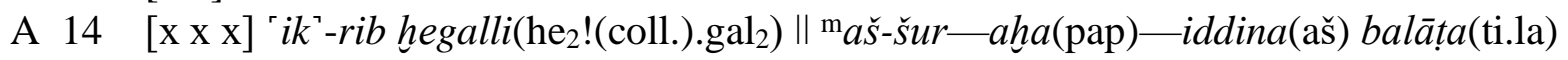
${ }^{\top} l u^{\top}$-tir

A $15{ }^{\top} l i b_{3}{ }^{\top}-b u \| h a-d u-u l i \check{s}-\check{s} a_{2}-k i n$

A 16 x x [le]-'ru'-bu\| ha-du-u ka-a-a-nu

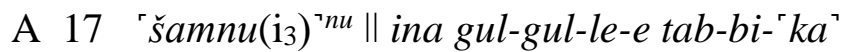

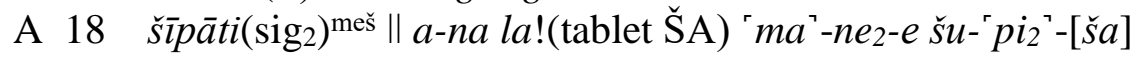

B 1 šamnū( $\left.\mathrm{i}_{3}\right)^{\text {meš }}$ ina gul?-gu'-le?-'e lu $t a b^{\top}-[k u]$ 


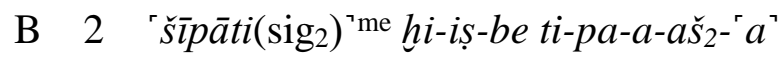

A $19 a k a l \bar{l}(\text { ninda })^{\text {meš }} r u{ }^{r} b a^{\urcorner}-a \|$ šikarī(kaš $)^{\text {meš }} t u-h i-d a$

A 20 i-na libs-bi-'šsu'-nu \|i-šar-tu 2 eš-ra-a-ni

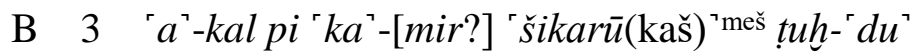

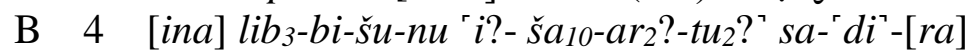

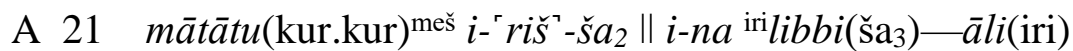

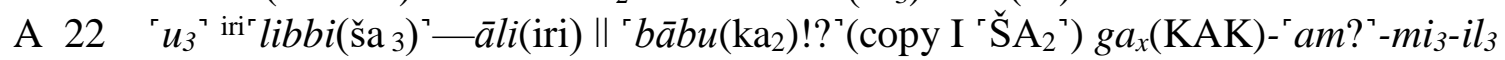

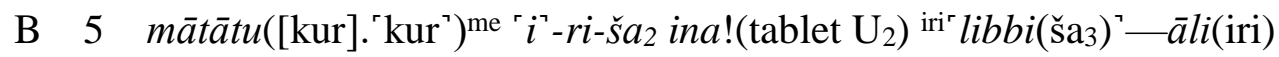

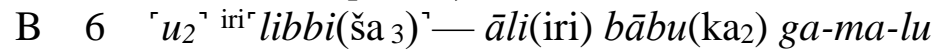

A $23{ }^{\mathrm{d}} a \check{s}-\check{s} u r \mathrm{~d} e l l i l(\mathrm{BAD}) \| g i-n u-u$

A $24 g i-{ }^{\circ} n u^{\top}-u_{2} \| s a-l i-m a-{ }^{-} k u-n u^{\top}$

B $7 a s^{2}-s ̌ u r ~ d[e l l i l(\mathrm{BAD})]^{\ulcorner} g i^{\top}-n u-u{ }^{\mathrm{r}} \mathrm{MIN}^{\top}(=g i-n u-u){ }^{\ulcorner} s a-l i ?-m u ?-k u^{\top}-n u$

A 25 qa-at ${ }^{r} r a^{\top}-[g a$ ? $]-{ }^{\top} t i^{\top} \|$ pat-ti-ra

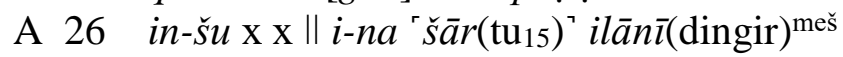

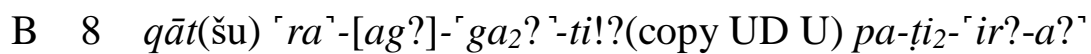

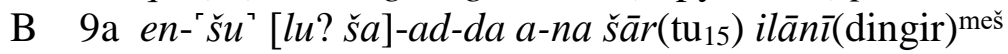

A $27 e b \bar{u} r u\left(\text { buru }_{14}\right)^{\ulcorner} \check{s} a^{\top}[m \bar{a} t i($ kur $)] \| l u-u \operatorname{damiq}\left(\operatorname{sig}_{5}\right)^{i q}$

A $28 a n-t u_{4}[\mathrm{x} \times \| l u-u]^{~ ' k a b ?^{\prime}-b a-r a}$

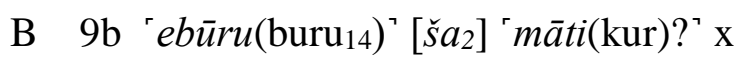

B Horizontal ruling

A $29 \times \mathrm{x}[\mathrm{x} \times \| \mathrm{x}]^{\top} i{ }^{\top}-k a b-b i r$

A $30[\mathrm{x} \times \mathrm{x} \times \| \mathrm{x}] \mathrm{x}-e$ il-la-ka

Translation of STT 87 11-30 (A) // STT 371 1-9 (B)

Obverse

A 11 Fill, fill their chests [with joy]!

A 12 [O Aššr] (and) Ellil, bless the Inner City (= Assur)!

A 13 Fill to their necks [with ...]!

A $14 \quad[. .$.$] prayer for plenty, may Esarhaddon restore life.$

A 15 May a joyful heart be established,

A 16 may ... (and) constant joy enter.

A 17 Pour oil into skull-shaped pots!

A 18 Have countless amounts of wool produced!

B 1 May oil be poured into skull-shaped pots.

B 2 You shall produce wool as yield. 
A 19 Make great the bread, supply beer copiously!

A 20 Go straight for prosperity among them!

B 3 The bread of the mouth is heaped up, the beer is copious.

B 4 Direct prosperity among them!

A 21 The lands rejoice in the Inner City (= Assur)

A 22 and, as for the Inner City (= Assur), the gate is merciful.

B 5 The lands rejoice in the Inner City (= Assur)

B 6 and, as for the Inner City (= Assur), the gate is mercy.

A 23 O Aššur (and) Ellil, fixed offerings,

A 24 fixed offerings are concord with you.

B 7 O Aššur (and) [Ellil], fixed offerings, ditto (= fixed offerings) are concord with you.

A 25 Remove the hand of malice,

A 26 the weak man ... into the breath of the gods;

B 8 Remove the hand of malice,

B 9a may the weak man be drawn to the breath of the gods.

A 27 May the harvest of [the land] be good,

A 28 [may] the ear of barley (and) [...] be very plump.

B 9b The harvest [of] the land ...

B Horizontal ruling

A $29 \quad \ldots[\ldots]$ it shall become plump,

A $30 \quad[\ldots] \ldots$ it shall come.

Transliteration of STT 87 rev. 2'-14' (A)

Reverse

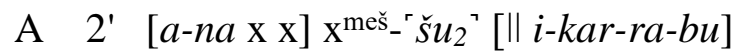

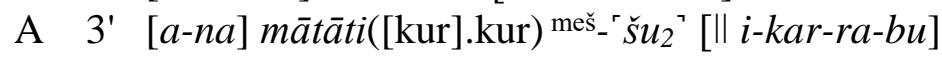

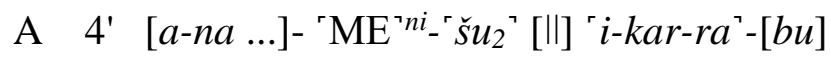

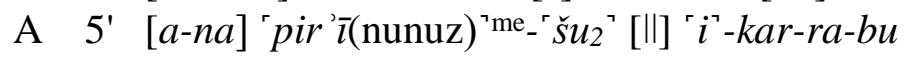

A 6' $[a-n a]^{r} m \bar{a} r(\mathrm{dumu})^{\top} u m-[m a n] \| i-k a r-r a-b u$

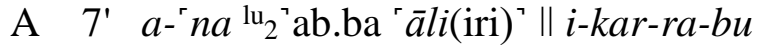

A $\quad 8{ }^{\prime} \quad u_{4}-m u^{\top} l i-i s^{\top}-m u \| \check{s} a^{\mathrm{d}} n a b \hat{u}\left(\mathrm{na}_{3}\right)$

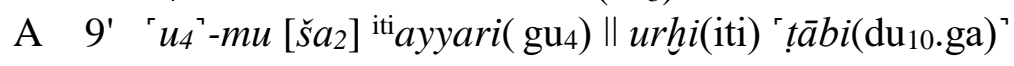

A 10' 'im-nu'-[ku-nu] šumēlu(gub $\left.{ }_{3}\right)-k u-n u \| s \bar{u} q($ sila $) \bar{a} l i($ iri $)-s ̌ u_{2}$ a-na e-te-qi 


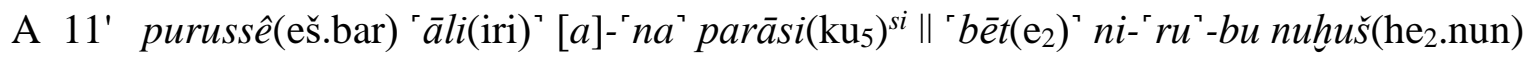
kuzub(hi.li)

A $12^{\prime} s \bar{u} q$ (sila) 'ni'-ti-qu\|i-ri-ia-aš2 $\bar{a} l u$ (iri)

A 13' is-'qu' nindabêe(nidba) meš || rabbûti(nun.na) lis-' ri' -qu

A 14' x 'tuppu(im)?' || MA 'MA?' U

Double ruling

Translation of STT 87 rev. 2'-14' (A)

Reverse

A 2' [They invoke blessings upon] his (= Esarhaddon's) [...] ...s,

A 3' [they invoke blessings upon] his lands.

A 4' They invoke blessings [upon] his [...] ...s,

A 5' they invoke blessings [upon] his descendants.

A 6' They invoke blessings [upon] the scholars,

A 7' they invoke blessings upon the city elders:

A 8' 'The day is the run of Nabû,

A 9' a day [of] Ayyaru, a favourable month.

A 10' On [your] right (and) on your left, for going along the street of his (= Nabû's?) city,

A 11' for deciding the decisions of the city, wherever we enter, there is abundance (and) attractiveness.

A $12^{\prime}$ The city rejoices at the street that we go along,

A 13' may they scatter shares (and) very big food offerings.'

A $14 '$... tablet ...

Double ruling

Selected Notes on Edition

A 11. A reading pan-di-šsu-un, 'their chests', is preferred given A 13: ki-šs $a_{2}-d i$-š $u_{2}-n u$, 'their necks'. The two lines open successive couplets and probably have a degree of parallelism (cf. Livingstone 1989: 24-25; Van Buylaere 2011a). The possessive suffix is understood as referring to the people of the city of Assur.

A 18 // B 2. The traces in B 2 favour hi-iṣ-be ti-, 'yield, you ...', rather than 'hi $h{ }^{-}-i s-{ }^{-} s a{ }^{\prime}-t i$, 'understanding', which is also difficult in terms of sense (cf. Livingstone 1989: 25). The variant verbal forms at the end of A 18 // B 2 are difficult but are probably cognates. They can tentatively be read as forms of epēšu, with A 18: $\check{s} u-{ }^{\ulcorner} p i_{2}{ }^{7}-[\check{s} a]$, 'have produced', Š imperative

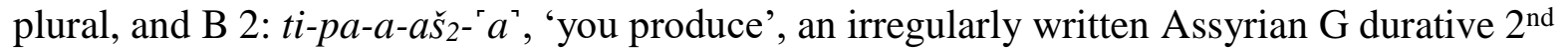

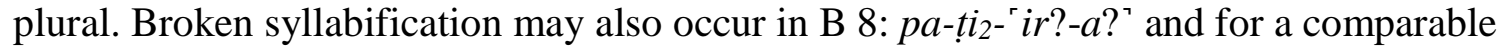
Assyrian form see STT 87 33: te-pa-ša $a_{2}$. Livingstone (1989: 25) and Van Buylaere (2011a) propose A 18: $\check{s} u-{ }^{-} b i^{\prime}-[\check{s} a]$, 'gather', D imperative plural of $\check{s} a b \bar{a} \check{s} u$, but do not propose any meaning for the end of B 2 .

A 19 // B 3. The variant in B 3 is difficult. Livingstone (1989: 25) and Van Buylaere (2011c) propose reading B 3: ' $a^{\urcorner}-k a l ~ p i-{ }^{r} k a^{\urcorner}[\mathrm{x}(\mathrm{x})]$, 'the bread of your mouth [...]', but a $2^{\text {nd }}$ singular 
possessive suffix is awkward in this context and a verbal form is more likely. However, the suggested reading B 3: ' $a^{\prime}$-kal pi ' $k a^{\prime}$-[mir?], 'bread of the mouth [is heaped up]', is a speculative one.

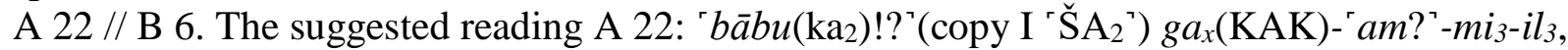
'the gate is merciful', with the adjective gammilu used predicatively, reflects the duplicate B 6: $b \bar{a} b u\left(\mathrm{ka}_{2}\right)$ ga-ma-lu, 'the gate is mercy'. However, the proposed reading in A 22 is very uncertain, involving emendation and a speculative sign value.

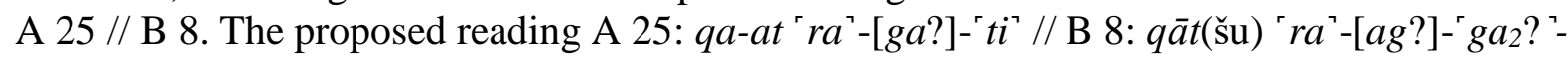
$t i !$ ?(copy UD U), 'the hand of malice', fits the traces and the context, although uncertainty remains. The couplet would work well if the first line is a request to the gods to remove a malign force (A 25 // B 8) and the second line is a celebration of divine protection (A $26 / /$ B 9a). On $\check{s} \bar{a} r\left(\mathrm{tu}_{15}\right)$ ilān̄in(dingir) ${ }^{\text {meš }}$, 'the breath of the gods', as a benevolent force see e.g. CAD Š 17/2 13839.

A rev. 4'-12'. These lines have been usefully discussed by Stadhouders (2013: 319).

A rev. 7'. The Neo-Assyrian equivalent to ${ }^{\mathrm{lu}_{2}} \mathrm{ab}$.ba in the phrase ${ }^{\mathrm{r} \mathrm{lu}_{2}}{ }_{2} \mathrm{ab} . \mathrm{ba}$ ' $\bar{a} l i($ iri) ', 'elders of the city', is uncertain but Van Buylaere (2011a) proposes pařsumüt.

A rev. 14'. This line is difficult. Despite the lack of a preceding ruling, might this be a rubric or even a line of commentary in the style of the latter part of STT 371 (B 13-19)? If the signs were tentatively read A rev. 14': 'mu?-ši?' || ma- 'šu?'-u, then B 15: $m u$-ši, 'night', might be relevant or A rev. 14' might contain two forms of the root $m \check{s}$ ', 'to forget', although this has no obvious relevance.

\section{Setting, Protagonists and Voice}

This composition of prayer and praise focuses on the city of Assur. Assur, Assyria's first political capital, retained a unique high status as a religious centre at the core of the Assyrian Empire until its fall and the deified city, rendered here as Aššur, was the national god of Assyria, the land of Aššur (e.g. Holloway 2002: 65-68). In this composition the city of Assur is given the title irilibbi(ša ${ }_{3}$ )-ăli(iri), 'the Inner City' (A 12; A 21-22 // B 5-6; Postgate 1985: 98; George 1993: 443). There are intermittent references to topographical features, $b \bar{a} b u$, 'gate', libittu, 'brickwork', and süqu, 'street' (A 22 // B 6; A 31; A rev. 10'; A rev. 12'). As preserved, there is no direct reference to Ešarra, the principal temple complex of the city and god Aššur and of Assyria, but the offerings to Aššur and Ellil would have been made there. The Nabû procession involves going along the street but, as preserved, no Nabû temple is mentioned.

Prayers and statements are addressed directly to the pair of gods Aššur and Ellil, who occur twice in the vocative and are referred to by second-person plural forms, usually imperatives (A 11-12; A 17-20 // B 2, 4; A 23-25 // B 7-8; A 33). Although the god Aššur, as head of the Assyrian pantheon, could be syncretised with Ellil, these plural forms suggest that in this composition Aššur and Ellil are treated as paired but distinct deities (George 1993: 185-86). Esarhaddon, whose theophoric name credits the king's birth to Aššur, is referred to in the third person: he is named as the subject of a third masculine singular precative verb in a prayer (A 14) and is the referent of the possessive suffix -š $u_{2}$ (A rev. 2'-5'). He is probably also once addressed directly using a second masculine singular imperative (A 13). This composition is mostly a third-person narrative. Third feminine plural forms refer to mātātu, 'the lands' (A 4-6; A 21; A 30?) and third masculine plural forms to unspecified people in the city of Assur (A 11; A 13; A 20 // B 4; A rev. 13'), sometimes as participants in the procession celebrating the hunting run of Nabû (A rev. 2'-7'). As suggested by Stadhouders (2013: 319), six lines near the end of the composition are probably a direct quotation of the words spoken by participants in this ritual to the experts and city elders upon whom they are invoking blessings, although the experts should probably be understood as scholars rather than 
craftsmen (A rev. 8'-12'). The speakers are in first-person plural and their hearers are in second masculine plural (A rev. 10'-12').

\section{Synopsis and Exegesis}

As noted by Livingstone (1989: XXV-VI), the Assur composition focuses on the city and activities within it, emphasising prosperity and contentedness. As well as celebrating Assur's current well-being, there are repeated prayers for its continuance through blessings for the people in the city. A pervasive theme is abundance, particularly in the form of cult offerings to Aššur and Enlil to secure divine favour and happiness. As well as plentiful offerings, proper cultic observance in the city involved a procession dedicated to Nabû in Ayyaru. As expected, human communication with the divine was a combination of speech and action, involving prayer and praise on the one hand and offerings and a procession on the other. Because of the unique status of Assur, this cultic activity and rejoicing had a reach far beyond the current city and extended to future generations and the whole Assyrian Empire. In the Middle and Neo-Assyrian periods the provisions for the fixed offerings $\left(\operatorname{gin} \bar{a}^{2} \bar{u}\right.$, gin $\left.\hat{u}\right)$ for the Aššur temple in the city of Assur were supplied by high officials and by the Assyrian provinces according to a rota and this included grain and sesame, which could be processed to produce bread and beer on the one hand and oil on the other: the provision of these offerings was a fundamental national enterprise (Holloway 2002: 67-68, 100-108; Leichty 2011: no. 60 15'-16'; Postgate 2014: 89-146, including 108 ff. on foodstuffs and processing).

The first ten badly damaged lines of the composition are not edited here. They include two instances of $r i$ 'ăšu, 'to rejoice', with the lands (mātātu) understood as the subject (A 4: ' $i^{\prime}$ $r i \check{s}-\bar{s} a_{2}$; A 5: [i]- ${ }^{r} r i \breve{s}^{-}-\check{s} a_{2}$ ). Forms of $r i$ ' $\bar{a} \breve{u} u$ for rejoicing by the city and the lands also occur in A $21 / /$ B 5 and A rev. 12'. Isolated references to wealth (A 8: meš- $r e^{7}$-[e]) and playing, possibly signifying battle, (A 10: me-lu-lu) and possibly to overcoming the negative, in the form of enemies' recalcitrance (A 9: šip-șa- 'ti?'), may relate to the city's current state or to requested blessings. ${ }^{4)}$

The composition edited here begins with a pair of complementary couplets. The second couplet contains a prayer to the king Esarhaddon that he provide fullness for the people (mulli) and that through a prayer for plenty (ikrib hegalli) he might restore life (balațta lutīr) (A 13-14). As preserved, all the other prayers in the composition with an identifiable addressee are directed to the paired gods Aššur and Ellil. The couplet about Esarhaddon is preceded by a related couplet about Aššur and Ellil (A 11-12; on the relationship see under poetic structure below). In A 11-12 Aššur and Ellil are directly petitioned for fullness (mullâ mullâ) and the blessing of the Inner City $(k u r b \bar{a} l i b b i-\bar{a} l i)$. The prayers to Aššr and Ellil are for prosperity and bountiful cult offerings, including plentiful supplies of staple commodities, and for the joy that the resulting divine favour brings. A prayer for a joyful heart (libbu hadî) and constant joy (hadî kayyānu) form another couplet (A 15-16).

This is followed by two couplets of prayers for abundant supplies of four specific staples,

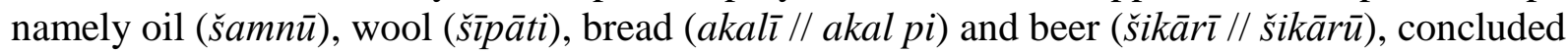
by a prayer for general prosperity (išartu) for the people (A 17-20 // B 1-4). The abundance of these four staples is expressed in a variety of ways. Although plural forms of all four nouns are not unexpected, of the eight writings, six are specifically marked as plural with meš or ${ }^{\text {me }}$, and the other two could stand for plural (A 17: ' $\check{S}^{2} a m n u\left(\mathrm{i}_{3}\right)^{\urcorner n u}$; B 3: ' $a^{\urcorner}-k a l$ pi). The plentifulness of the oil is indicated by the use of a rare word for a type of pot, since the oil is to be poured into gulgulle, 'skull-shaped pots' (A 17 // B 1). The word gulgullu or gulgullatu, 'skull', is rarely used for pots but it could signify a relatively large copper or bronze pot suitable for cooking. A booty list in the letter account of the eighth campaign of Sargon II includes 'copper skull-shaped pots' (TCL 3 392: gul-gul-lat erî(urudu)) and a work contract from the reign of Nebuchadnezzar II mentions 'one bronze kettle weighing three minas, a skull-shaped pot' (Nbk. 426 1-2: $1^{\text {en }}$ siparru(zabar) 
$m u$-šah-hni-nu ša ${ }_{2}^{r} 3$ ? manā(ma.na) $\left.{ }^{\urcorner} / g u l-g u l-l u\right)$. A mušahhinu-kettle was used for the preparation of fixed offerings ( ginû) in Uruk in the Late Babylonian period (Beaulieu 2003: 290). The abundance of wool is indicated in one manuscript by ana la manê, 'for not counting' (A 18) and in the duplicate by hiṣbe, '(abundant) yield' (B 2). The plentiful amounts of bread and beer and signified by the choice of verbs. One manuscript has the D imperatives rubbâ, 'make great', and tuhhida, 'supply copiously' (A 19) and the duplicate has the G stative forms 'kamir?', 'it is heaped up', if restored correctly, and tuhdū, 'they are copious' (B 3).

The next two couplets concern rejoicing through the divine mercy and concord granted to those who enter the Inner City and make fixed offerings to Aššur and Ellil. The lands rejoice in the Inner City (A 21 // B 5: mātātu iriššă ina libbi-āli; ri' $\bar{a} s ̌ u$ also occurs in A 4-5 and A rev. 12') and the gate of the Inner City is said to be merciful (A 22 // B 6: u libbi-āli bāabu gammil?//gamālu). In the second couplet fixed offerings, food and drink that was offered daily, are said to be concord with Aššur and Ellil (A 23-24 // B 7: ǎššr ellil ginû / gin $\hat{u}$ salìmākunu//salìmūkunu). The provinces supplied provisions for the fixed offerings for this temple according to a rota (Holloway 2002: 67-68, 100-108; Postgate 2014: 93-107). The title Inner City, a name for Assur, and the term ginû are stressed through carefully positioned repetition and this signals that these two couplets are of key importance for the composition as a whole.

Overcoming the negative and achieving the positive in the form of divine protection is sought in the following couplet (A 25-26 // B 8-9a). This is probably a prayer to Aššur and Ellil that they remove 'the hand of malice' (A 25 // B 8: qāt 'raggāti?' pattiirāa) and that as a result the formerly vulnerable weak man come under the protection of the gods (A 26 // B 9a: šār ilāni, literally 'the breath of the gods').

The theme of abundance is resumed by a harvest (ebüru) prayer which relates to these specific staples (A 27-29 // B 9b). Bread and beer usually depended upon barley, the most important crop, and the main source of vegetable oil was sesame, which was also harvested. This prayer probably has a couplet structure (see poetic structure below). The focus moves out from the city to the agricultural land that supported it and MS A preserves a prayer for a good harvest (A 27: $l \bar{u}$ damiq) and probably the swelling of the grain with two forms of $k b r$ (A 28: antu [... lū] 'kabbarā̄; A 29: ikabbir).

After a lacuna, the composition ends with a particularly propitious ritual performed in Assur on a specific day of the second month Ayyaru, namely the cultic procession celebrating the run by the god Nabû. According to a Neo-Assyrian letter, the consummation of the 'sacred marriage' of Nabû and Nanāya/Tašmētu earlier in Ayyaru was followed by Nabû's bull-hunting run on the eleventh day (Cole and Machinist 1998: 62, $221=S A A 13$ 70):

1 [ud] 11.kam2 ${ }^{\mathrm{d}}$ nabû(na3) uṣ-șa-a

$2 \check{s} \bar{e} p\left(\operatorname{gir}_{3}\right)-\check{s}_{2} i-p a-a \check{s}_{2} !-\check{s} a r$

3 a-na am-ba-as-si il-lak

4 ri-ma-a-ni i-du-ak

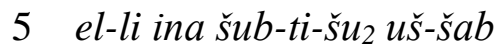

6 a-na 'šarri(lugal) ' [bēli(en)]-'ia!?

$7 u_{3}{ }^{r} b \bar{e} t i\left(\mathrm{e}_{2}\right) !-\check{s}_{2} u_{2}$ ! i!-kar!-rab!'

1 On the eleventh [day] Nabû will come out.

2 He will release his foot,

3 He will go to the game-park.

4 He will kill wild bulls.

5 He will ascend and sit in his seat.

6-7 He will bless the king, my [lord], and his house. 
The ritual expression of Nabû's post-coital hunt took the form of a procession by Nabû's statue and, after the statue had been reinstalled, the 'sacred marriage' festival concluded with Nabû blessing the king.

In a sequence of three damaged couplets all the lines probably share the same structure and concern the participants in the procession invoking blessings upon various recipients (A rev. 2'-7'). ${ }^{5}$ ) These include blessings for the king's lands (A rev. 3': ' $m a \bar{a} t \bar{a} t \bar{s} s u^{\prime}$ ) and descendants (A rev. 5': 'pir' 'išu'), so the ritual's geographical and temporal reach extends far beyond the contemporary city to encompass the Assyrian empire and generations of potential future kings. In the third couplet the focus returns to the actual city with the invocation of blessings upon 'mār ummân', 'experts', probably signifying 'scholars' rather than 'craftsmen', and 'lu ${ }_{2}$ ab.ba $\bar{a} l i$ ', 'city elders' (A rev. 6'-7'). Two elite urban cadres are singled out and the scholar who composed this work puts the experts in the leading position. The words spoken by the ritual participants are then quoted in direct speech in the final three couplets (A rev. 8'-13'). The speakers identify the current day in Ayyaru as the annual date in Assur's ritual calendar for the procession celebrating Nabû's run and characterize Ayyaru as $u r h i$ 't $\bar{a} b i$ ', 'a favourable month' (A rev. 8'-9'). To the hearers' right and left, for going along the city streets or making decisions for the city, the speakers say that there is abundance (nuhš $u$ ) and attractiveness (kuzbu) wherever they enter (A rev. 10'-11'). Going along the city streets and making decisions for the city are appropriate activities for the scholars and city elders who are the last named addressees (A rev. 6'-7'). As the celebration of a successful post-coital hunt, the procession gives rise to qualities with an erotic aspect along its route, namely abundance and attractiveness. In the final couplet the city rejoices at the street taken by the speakers in procession (A rev. 12': irì aš ālu; on ri'āšu in A 4-5 and A 21 // B 5 see above) and there is a prayer that shares and lavish food offerings may be scattered for the gods (A rev. 13': isqū nindabê rabbûti lisriqū:). This latter line may end the direct speech or the composition may have reverted to third person narrative. This key procession in the city's cultic year makes a fitting conclusion for the Assur composition and is important for the composition as a whole. For further bibliography on the run of Nabû and on Ayyaru in cult and as a favourable month and time of rejoicing see Stadhouders (2013). It is noteworthy that the composition ends with a description of a specific cultic event and a final petition that the appropriate offerings are made.

\section{Poetic structure}

The better preserved passages of the composition can be analysed as poetic lines grouped into couplets (A 11-28 // B 1-9b; A rev. 2'-13'). Before a ruling the excerpt in MS B ends with a line that spills over onto the side of the tablet and contains two poetic lines (A 26-27 // B 9ab). The final poetic line is the first line of a harvest prayer (A $27 / / \mathrm{B} 9 \mathrm{~b}$ ). The end point of the excerpt and the use of two forms of $k b r$ in the next two lines of the composition (A 28-29) might suggest that A $27 / /$ B $9 \mathrm{~b}$ is a monostich. However, given the prevalence of couplets in the rest of the composition and the fact that MS B is an excerpt on a less regularly written school tablet, it is more likely that A $27 / / \mathrm{B} 9 \mathrm{~b}$ is the first line of a couplet. For another instance of MS B having two poetic lines on one line of tablet see A 23-24 // B 7 and the discussion on sources above.

A striking feature of MS A is the double vertical ruling down the centre of the tablet on both obverse and reverse. This double ruling is related to the poetic structure. In a four-foot poetic line the text is written so that the double ruling corresponds to the mid-line caesura, shown most clearly in A 19, rev. 10'. In a three-foot poetic line the double ruling corresponds either to the boundary between the first and second feet (e.g. A 15, 17-18, 20) or to the boundary between the second and third feet (e.g. A 23, 25, 27, rev. 8'). There is also one highly emphatic poetic line that consists of just two simple feet and encapsulates the essential 
message of the poem (A 24). It is noticeable that, adjacent to the double ruling, some sequences of lines have one or more signs vertically aligned. This is most common after the double ruling (A 8-10: $\check{s} a$; A 9-10: $\check{s} a \mathrm{ME}$; A 15-16: ha-du-u; A 20-22: $i$ (possible dittography in A 22); A rev. 4'-8': i-kar-ra-bu), but can also precede it (A 4-5 i-riš-ša $a_{2}$ (if correctly restored; imprecise alignment); A 15-16: $b u$ ).

As an example of the composition's poetic complexity a couplet of prayer to Aššur and Ellil (A 11-12) and the following couplet of prayer to Esarhaddon are elaborately interrelated (A 13-14). This involves the use of imperative forms of mullû (A 11: mullâ $\|$ mullâa $=$ feet $2 / 4$ and 3/4; A 13: mulli $\|=$ foot 2/3); a degree of parallelism between body-parts (A 11: pandī̌sun (accusative) $=$ foot 4/4; A 13: $\|$ ana kišădǐšunu = foot 3/3); related but contrasting divine and royal names (A 12: [aššur] ellil $\|=$ feet $1 / 4$ and 2/4; A 14: $\|$ ǎšsur-aha-iddina = foot 3/4); and cognate forms of the root $k r b$ (A 12: $\| k u r b \bar{a}=$ foot 3/4; A 14: ikrib hegalli $\|=$ foot 2/4). The recipients of the blessings are specified in A 12 and the nature of the blessings in A 14.

\section{Literary and Historical Contexts}

The Assur composition was edited by Livingstone together with a celebration of the city of Arbela and a celebration of the city of Uruk (Livingstone 1989: nos 8-10). Among the examples of Neo-Assyrian poetry these three compositions were grouped together as 'hymns to cities', with the proviso that the term 'hymn' was one of convenience and 'elements of prayer' were also involved (Livingstone1989: XXI, XXV-VI). Livingstone also noted a related example of Babylonian poetry, a composition on a Kouyunjik tablet relating to the cult of the city of Babylon (Livingstone 1989: XXV, XXXIV; Foster 2005: 876-77). For discussion of the problems of imposing modern genres on ancient compositions, and on hymns as a specific variety of prayer see Lenzi $(2011: 1-23,57)$. While each of these four works has a distinct character, nevertheless they are all compositions of prayer and praise that focus on a particular city.

It has been noted by scholars including Livingstone (1989: XXV-VI) and George (1987: 37-39) that these compositions can be related to earlier compositions from southern Mesopotamia celebrating temples and cities but that they lack any close Babylonian parallels. These compositions probably constitute an Assyrian innovation, albeit one that draws on material from southern Mesopotamia. The composition celebrating Assur contains a prayer addressed to Esarhaddon (A 14) and can thus be dated to the reign of this king. The composition is an expression of Neo-Assyrian ideology and theology centred on the provision of offerings to Aššur and Ellil in the city of Assur as a national enterprise that was necessary to secure divine favour. This is very much in keeping with Esarhaddon's reign. His inscriptions describe a major renovation of Ešarra, Aššur's temple in Assur (Leichty 2011: nos 57 (two copies dated to $679 \mathrm{BC}$ ), 58, 59, 76). His renovating of Ešarra and his rebuilding of Esagil, Marduk's temple in Babylon, were regularly paired as highlights of royal achievement and this reflects the status of these two temple complexes as the epicentres of Assyrian and Babylonian national cult (Leichty 2011: nos 10 3, 17 6'-7', 43 8-9, 48 36, 60 17'50', 74 4-5, and passim). Esarhaddon's chronic ill health and desire to make amends for the sack of Babylon by his father Sennacherib all contributed to a particularly anxious desire to please the gods and he also faced the challenge of welding his empire together, including Babylonia (Porter 1993: 119-53; Holloway 2002: 358-72; Leichty 2011: 1-3). It is quite possible that all the four compositions mentioned above date to the reign of Esarhaddon. ${ }^{6}$ )

The Assur composition was copied in toto onto one tablet and a duplicate passage, with significant variants, was copied as an excerpt onto another. Both surviving manuscripts were written as part of scribal training and were found in a scholarly library in Huzirina. Manuscript A (STT 87), containing the composition and a colophon, was written by a junior apprentice scribe whose Assyrian name celebrates Aššur and whose father was a scribe of the 
city of Assur. Manuscript B is an excerpt tablet (STT 371), which has an overall theme of Assyrian royal cult. Thus, a composition of prayer and praise celebrating the traditional capital city Assur as the unifying, religious centre of the Assyrian Empire has partially survived on two scribal education tablets from the imperial periphery.

\section{Endnotes}

1) The convention is followed here of rendering the city as Assur but the god as Aššur, but this distinction in spelling is only one of modern convenience.

2) The fragment S.U. 52/43 = STT 87A may be an indirect join to STT 87 (Gurney and Finkelstein 1957: 7, 13, CIX). Deller (1965: 461) suggested that S.U. 52/336 = STT 375 may be another such fragment. For the former see also Van Buylaere (2011b) and for the latter <http://cdli.ucla.edu/P338690> (accessed 11/06/2014).

3) STT 87 has the correct excavation number but SU 51/026 + SU 51/124 is listed as an accession number.

4) For examples of battle as play, see e.g. $C A D \mathrm{M} / 2$ 15-17. Assurbanipal's hymn to Ištar of Nineveh and Ištar of Arbela celebrates his conquest of the recalcitrant (Livingstone 1989: no. 3, 21: [x] 'mātāte(kur) 'meš šip-șa-a-te, '[...] recalcitrant lands'; rev. 12: šip-șu-u-te, 'the recalcitrant').

5) It is less likely that A rev. 2'-5' should be understood as blessings by Aššur and Ellil.

6) As I will argue in a separate article in preparation.

\section{Reference List}

Baker, $H \cdot D \cdot$

2002 The Prosopography of the Neo-Assyrian Empire 3/1. Helsinki: The NeoAssyrian Text Corpus Project.

Beaulieu, P.-A.

2003 The Pantheon of Uruk during the Neo-Babylonian Period- Leiden: Brill, STYX.

Capraro, $M$.

2001 La biblioteca di Sultantepe. Unpublished Ph.D. thesis. Napoli: Istituto Universitario Orientale di Napoli.

Clancier, $P$.

2012 Qurdi-Nergal's house in Huzirina.

<http://oracc.museum.upenn.edu/cams/gkab/contexts/huzirina/> in The Geography of Knowledge in Assyria and Babylonia: A Diachronic Analysis of Four Scholarly Libraries, directed by E. Robson and S. Tinney. Accessed 11/06/2014.

Cole, S. W., and Machinist, P.

1998 Letters from Priests to the Kings Esarhaddon and Assurbanipal. State Archives of Assyria XIII. Helsinki: Helsinki University Press.

Deller, K.

1965 Neuassyrisches aus Sultantepe. Or 34: 457-77.

Foster, $B \cdot R$. 
2005 Before the Muses: An Anthology of Akkadian Literature. $3^{\text {rd }}$ edition. Bethesda: CDL Press.

2007 Akkadian Literature of the Late Period. Münster: Ugarit-Verlag.

George, $A \cdot R$.

1987 A Neo-Assyrian Literary Text. SAAB 7: 37-41.

1993 Babylonian Topographical Texts. Leuven: Peeters Press.

2003 The Babylonian Gilgamesh Epic: Introduction, Critical Edition and

Cuneiform Texts 1-11. Oxford: Oxford University Press.

Gesche, P. D.

2001 Schulunterricht in Babylonien im ersten Jahrtausend v. Chr. Münster:

Ugarit-Verlag.

Glassner, J.-J.

2004 Mesopotamian Chronicles. Atlanta: Society of Biblical Literature.

Gurney, O. R., and Finkelstein, J. J.

1957 The Sultantepe Tablets I. London: British Institute of Archaeology at Ankara.

Gurney, O. R., and Hulin, P.

1964 The Sultantepe Tablets II. London: British Institute of Archaeology at Ankara.

Holloway, S. W.

2002 Aššur is King! Aššur is King! Religion in the Exercise of Power in the Neo-Assyrian Empire. Leiden: Brill.

Hunger, $\mathrm{H}$.

1968 Babylonische und assyrische Kolophone. Kevelaer: Butzon \& Bercker.

Lambert, W. G.

1959 The Sultantepe Tablets: A Review Article. RA 53: 119-38.

Leichty, E.

2011 The Royal Inscriptions of Esarhaddon, King of Assyria (680-669 BC). RINAP 4.

Winona Lake: Eisenbrauns.

Lenzi, A.

2011 Reading Akkadian Prayers and Hymns: An Introduction. Atlanta: Society of Biblical Literature.

Livingstone, A.

1989 Court Poetry and Literary Miscellanea. State Archives of Assyria III. Helsinki: Helsinki University Press.

Mair, G. H.

1909 Wilson's Arte of Rhetorique, 1560. Oxford: Clarendon Press.

Porter, B. N.

1993 Images, Power, and Politics: Figurative Aspects of Esarhaddon's Babylonian Policy.

Philadelphia: American Philosophical Society.

Postgate, J. N.

1975 Hुarrān. Pp. 122-25 in Reallexikon der Assyriologie und Vorderasiatischen Archäologie 4, ed. D. O. Edzard. Berlin: Walter de Gruyter.

1985 rev. K. Nashef, Die Orts- und Gewässernamen der mittelbabylonischen und mittelassyrischen Zeit. Répertoire Géographique des Textes Cunéiformes 5. AfO 32: 95-101. 2014 Bronze Age Bureaucracy: Writing and the Practice of Government in Assyria.

Cambridge: Cambridge University Press.

Radner, K. 
2012 Sultantepe. Pp. 287-88 in Reallexikon der Assyriologie und Vorderasiatischen Archäologie 13, ed. M. P. Streck. Berlin: Walter de Gruyter.

Robson, E.

2011 The Production and Dissemination of Scholarly Knowledge. Pp. 557-76 in The Oxford Handbook of Cuneiform Culture, ed. K. Radner and E. Robson. Oxford: Oxford University Press.

2013 Reading the Libraries of Assyria and Babylonia. Pp. 38-56 in Ancient Libraries, ed. J. König, K. Oikonomopoulou and G. Woolf. Cambridge: Cambridge University Press.

Stadhouders, $\mathrm{H}$.

2013 A Time to Rejoice: the Egalkura Rituals and the Mirth of lyyar. Pp.

301-324 in Time and History in the Ancient Near East, ed. L. Feliu, J. Llop, A. Millet Albà and J. Sanmartin. Proceedings of the $56^{\text {th }}$ Rencontre Assyriologique Internationale at Barcelona 26-30 July 2010. Winona Lake: Eisenbrauns.

Van Buylaere, G.

2011a STT 1, 087. <http://oracc.museum.upenn.edu/cams/gkab/corpus/> in The Corpus of Ancient Mesopotamian Scholarship: The Geography of Knowledge in Assyria and Babylonia: A Diachronic Analysis of Four Scholarly Libraries, directed by E. Robson and S. Tinney. Accessed 11/06/2014.

2011b STT 1, 087a. <http://oracc.museum.upenn.edu/cams/gkab/corpus/> in The Corpus of Ancient Mesopotamian Scholarship: The Geography of Knowledge in Assyria and Babylonia: A Diachronic Analysis of Four Scholarly Libraries, directed by E. Robson and S. Tinney. Accessed 11/06/2014.

2011c STT 2, 371. <http://oracc.museum.upenn.edu/cams/gkab/corpus/> in The Corpus of Ancient Mesopotamian Scholarship: The Geography of Knowledge in Assyria and Babylonia: A Diachronic Analysis of Four Scholarly Libraries, directed by E. Robson and S. Tinney. Accessed 11/06/2014. 